\title{
The impact of information and communications technology infrastructure and complementary factors on intra-African Trade
}

\author{
Felix Olu Bankole, Kweku-Muata Osei-Bryson and Irwin Brown
}

\begin{abstract}
:
Trade is one of the cornerstones of socio-economic development for Africa. Intracontinental trade stimulates productive capacity and competitiveness in nations through exposing domestic industries to competition. The purpose of this study was to investigate how information and communications technology (ICT) infrastructure impacts on intra-African trade, taking into account other relevant factors that also influence trade such as Institutional Quality and Educational Attainment. Archival data about Telecommunications Infrastructure (a key indicator of ICT infrastructure), Institutional Quality and Educational Attainment and Trade Flows (Export and Import) from 28 African countries were used as empirical evidence. The research employed structural equation modeling with partial least squares to analyze data. The empirical analysis shows that the Telecommunications Infrastructure has a major impact on intra-African trade. Interacting factors such as Institutional Quality and Educational Attainment also play a role in influencing intra-African trade.
\end{abstract}

\section{Introduction}

The past few decades have witnessed a growth in the use of information and communications technology (ICT) infrastructure as a mechanism for development in many countries (Bollou, 2010; Shirazi, 2010). The growth in worldwide ICT has contributed to globalization, enabling integration of financial markets among groups of countries (World Trade Organization [WTO], 2008). This has led to intraregional cooperation and trade (Christodoulopoulou, Garofalakis, \& Koskeris, 2006). Trade can be one of the cornerstones of socio-economic development (International Monetary Fund [IMF], 2008). Regional trade creates an enlarged regional economy from small and not necessarily equal national economies thereby promoting growth and socio-economic development (WTO, 2001). Intra-regional trade is important because it can stimulate productive capacity and competitiveness through exposing domestic industries to intra-regional competition (United Nations Economic Commission for Africa [UNECA], 2010).

Trade affects the income of the poor through its effect on economic growth, employment creation, revenue, consumer prices and government spending (UNECA, 2010; WTO, 2001). For example, the emergence of China and India as 
economic powers through trade has contributed to a significant drop in world poverty (UNECA, 2010; WTO, 2003). While many countries have benefited from increased trade, Africa's share in world trade has declined from $6 \%$ to $2 \%$ in the last two decades (South Africa excluded) (IMF, 2008; UNECA, 2010). When looking at intra-African trade, the pattern of African exports is influenced by past links with the rest of the world (United Nations Conference on Trade and Development [UNCTAD], 2009; UNECA, 2012). For example, 80\% of exports from African countries are directed externally, toward markets such as the European Countries (EU) and the USA, while only $12 \%$ are directed toward other African nations (UNCTAD, 2009; UNECA, 2010). This trend is not encouraging when compared with other regions, where $40 \%$ of North American trade occurs with other North American countries and 63\% of Western European trade takes place between European nations (WTO, 2008). Intra-African trade hence has the potential to enhance development and regional integration among African countries (UNCTAD, 2009; UNECA, 2010, 2012). It can serve as a powerful driver of African poverty alleviation, economic growth and human development (UNECA, 2010). African policy-makers, in collaboration with their pan-African institutions such as the African Union Commission, the United Nations Economic Commission for Africa (UNECA), the Regional Economic Communities, the African Development Bank and other international organizations (e.g. International Telecommunication Union [ITU]) have embarked on the process of reversing the present trends in intra-African trade through investments in ICT infrastructure, a free trade area, a customs union and a common market (UNECA, 2010).

In this article, following research question is posed - What is the impact of ICT infrastructure and other key complementary factors on intra-African trade? The rest of this article is arranged as follows: Section 2 describes a trend analysis of ICT infrastructure in Africa. Section 3 explains the trends on intra-African trade. Section 4 presents trade background information for a select 28 countries by regional grouping. In Section 5, an overview of ICT infrastructure in these countries is given. Section 6 outlines the theoretical foundations for the study. Sections 7-9 present the research methodology, the description of the data and the data analysis, respectively. The last section provides for a summary, recommendations and conclusion.

\section{Trends of ICT infrastructure in Africa}

The ICT expansion has brought basic telecommunications services within the reach of many Africans. Rapid growth has been as a result of high levels of investments in mobile network infrastructure (UNECA, 2010). In 2008, 263 million telephone subscribers (fixed and mobile) were found in Sub-Saharan African, representing about $32 \%$ of the population (International Telecommunication Union [ITU], 2009; World Bank, 2011). By 2013, this proportion was estimated to have doubled to $65 \%$ of the population (ITU, 2013). Although ICT infrastructure has improved in all the countries in Africa, the rate of expansion varies from one country to another. For instance, as at 2011, in Ethiopia, Somalia and Eritrea mobile phone subscriptions were less than $17 \%$ of the population, whereas in each of South Africa, Botswana, Gabon and Seychelles the rate surged to more than 100\% (ITU, 2013). 
Mobile penetration rates increased from 0.6\% to 32\% between 1998 and 2008 (World Bank, 2011). The 2013 estimates are at about 64\% (ITU, 2013). The mobile market is becoming more evenly distributed across the region. For instance, South Africa accounted for $86 \%$ of African mobile subscribers in 1998, but this dropped to $18 \%$ in 2008 and $15 \%$ in 2011 (ITU, 2013; World Bank, 2011). Nigeria accounted for one-quarter of the continent's total mobile penetration in 2008, overtaking South Africa as the biggest mobile market in Africa (World Bank, 2011). Nigeria's proportion decreased slightly to $22 \%$ in 2011, as growth rates in South Africa accelerated (ITU, 2013).

The fixed line penetration rate in Africa was 1.3 subscribers per 100 people in 1998. This rose to 1.5 in 2007 and later fell to 1.4 in 2008 (ITU, 2009; World Bank, 2011), with an estimate of 1.3 in 2011 (ITU, 2013). The drop has been due to the greater accessibility and affordability of mobile telephony.

Broadband Internet connections on the continent increased from zero at the beginning of 2000 to 19 million in 2010 (World Bank, 2011). Even though, this is only about $2 \%$ relative to the population of the region, the rate of growth averaged 200\% per year between 2005 and 2009. South Africa and Nigeria accounted for $43 \%$ of the total number of mobile subscribers and $80 \%$ of broadband Internet subscribers in Africa (World Bank, 2011).

\section{Trends of intra-African trade}

In Africa, there has been a long history of trade flow and regional integration since the wave of independence in the 1960s; yet, the proportion of intra-African trade remains low when compared with developed and developing regions of the world (UNCTAD, 2009; UNECA, 2010). Trade links in Africa are oriented toward Europe (UNCTAD, 2009; UNECA, 2010, 2012). These links were inherited at independence by different countries at different times (UNCTAD, 2009). Several African countries still produce commodities for the industries of their previous colonial power (UNCTAD, 2009; UNECA, 2010). As shown in Figure 1 (UNCTAD, 2008), the continent had the lowest proportion of intra-regional trade in 2006. Both intra-African exports and intra-African imports were below 10\%, far below those found in other regions of the world.

Figure 2 (UNCTAD, 2009) reveals that low intra-African trade has been a feature since the 1960s. Figure 2 also shows that Africa has consistently had the lowest proportion of intraregional trade as compared to other regions of the world. This has been attributed to trade controlled by previous colonial rulers, whereby African countries have been constrained in their ability trade between each other (UNCTAD, 2009). Only in the late 1990s intra-African exports rise above 10\% before falling below again over the period 2000-2006. The decline in this period was due to the fact that Africa's trade with the rest of the world increased much faster than intra-African trade (UNCTAD, 2009). For example, the intra-African trade between 1999 and 2006 increased by $13.64 \%$ on average per year, while 
Africa's trade with the USA and China increased by $27.57 \%$ and $60.85 \%$ on average per year, respectively (UNCTAD, 2009).

The modest increase in intra-Africa trade since the 1980 s has been attributed by UNCTAD (2009) to three factors: (1) the introduction of structural adjustment programs by the World Bank and the International Monetary Fund (IMF), which encouraged regional trade; (2) the abolition of apartheid in South Africa which strengthened economic ties with its neighboring countries; and (3) the establishment of regional trade agreements such as amongst Southern African Development Community (SADC) countries.

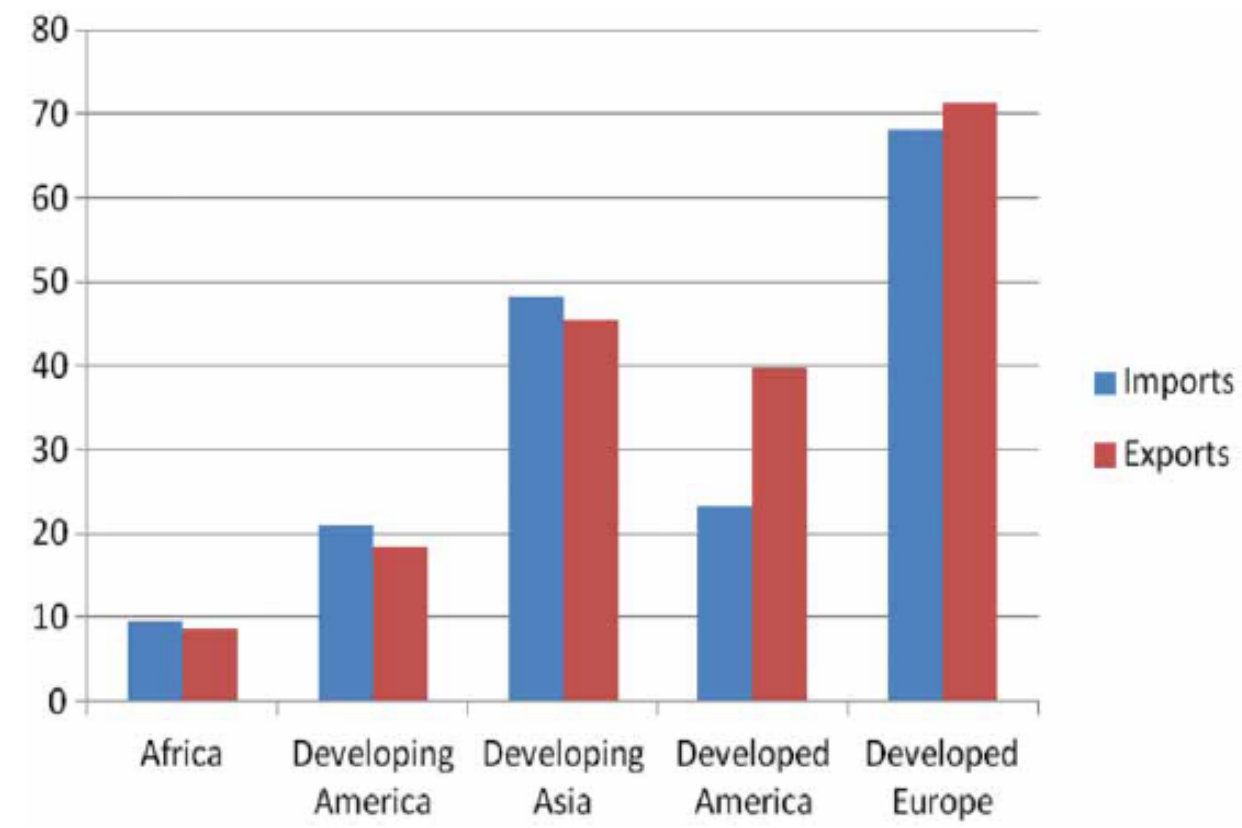

Figure 1. Intra-African trade as compared with other continents in 2006 (UNCTAD, 2008).

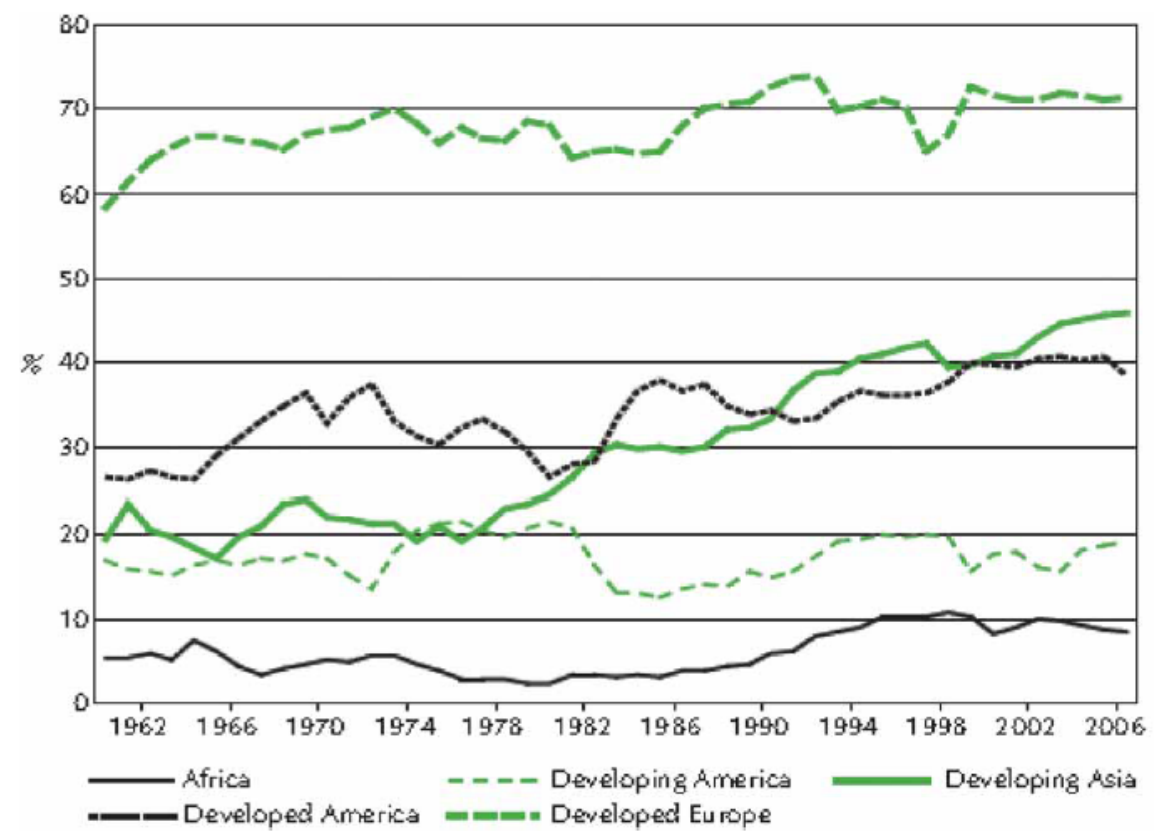

Figure 2. Intra-regional exports as proportion of total trade (UNCTAD, 2009). 
Table 1 shows that despite the low levels of intra-regional trade, Africa has had the second highest rate of growth in intra-regional trade (exports) relative to other regions between 1960 and 2006. Developing Asia had the highest growth rates.

\section{Intra-African trade in select African countries}

Twenty-eight African countries for which full data concerning intra-African exports and imports were available for the period 2000-2007 are given in Table 2. The table shows that South Africa is a dominant force both in terms of exports to and imports from Africa. The value of goods exported from South Africa represents 29.6\% of total intra-African export trade for the period 2000-2007 (US\$5.9 billion), followed by Nigeria with $10.4 \%$ of intra-African exports (US $\$ 3$ billion). Other exporters to African markets were Cote d'Ivoire and Kenya with $9.3 \%$ and $4.7 \%$, respectively. With regard to imports, South Africa ranked as the major importer of goods from Africa accounting for $10.4 \%$ of imports, followed by Ghana (5.9\%), Cote d'Ivoire (5.8\%) and Nigeria (5.1\%), respectively.

The countries were grouped in Table 2 into four regions as follows: SADC, Economic Community of West African States (ECOWAS), East Africa and North Africa. The order of regions in terms of intra-regional exports as a share of total exports within Africa between 2000 and 2007 was SADC (33\%), ECOWAS (22\%), East Africa (as part of COMESA [Common Market for Eastern and Southern Africa] - 16\%) and North Africa (as part of UMA [Arab Maghreb Union] - 9\%), respectively (UNECA, 2010).

Table 1. Growth in intra-African trade (UNCTAD, 2009).

\begin{tabular}{lrrr}
\hline \multicolumn{3}{l}{ Intra-regional trade (exports as a percentage of total exports) } \\
\cline { 2 - 4 } & \multicolumn{3}{c}{ Period } \\
Countries & 1960 & 2006 & Growth (\%) \\
\hline Africa & 5.58 & 8.68 & 55.43 \\
Developing America & 15.97 & 11.41 & 16.11 \\
Developing Asia & 21.06 & 45.54 & 116.28 \\
Developed America & 26.64 & 39.8 & 49.41 \\
Developed Europe & 61.28 & 71.38 & 16.47 \\
\hline
\end{tabular}


Table 2. African countries ICT development status (ITU, 2011) and exports to and imports from African countries in US\$ millions (UNECA, 2010).

\begin{tabular}{lcccccc}
\hline Countries & Group & $\begin{array}{c}\text { IDI level } \\
(2010)\end{array}$ & $\begin{array}{c}\text { Exports } \\
(2000-2007)\end{array}$ & Share $(\%)$ & $\begin{array}{c}\text { Import } \\
(2000-2007)\end{array}$ & Share (\%) \\
\hline Mauritius & SADC & Medium & 169.5 & 0.9 & 386.1 & 1.8 \\
Botswana & SADC & Medium & 148 & 0.7 & 18 & 0.1 \\
Namibia & SADC & Low & 148 & 0.7 & 18 & 0.1 \\
South Africa & SADC & Medium & 5859.0 & 29.6 & 2205.1 & 10.4 \\
Swaziland & SADC & Low & 148 & 0.7 & 18 & 0.1 \\
Madagascar & SADC & Low & 35.02 & 0.2 & 191.7 & 0.9 \\
Lesotho & SADC & NA & 148 & 0.7 & 18 & 0.1 \\
Mozambique & SADC & Low & 30.1 & 1.5 & 847.9 & 4.0 \\
Benin & ECOWAS & Low & 123.6 & 0.6 & 259.6 & 1.2 \\
Burkina Faso & ECOWAS & Low & 50.9 & 0.3 & 360.3 & 1.7 \\
Cape Verde & ECOWAS & Medium & 1 & 0 & 34.7 & 0.2 \\
Cote d'Ivoire & ECOWAS & Low & 1838.9 & 9.3 & 1236.1 & 5.8 \\
Gambia & ECOWAS & Low & 8.3 & 0 & 113.7 & 0.5 \\
Ghana & ECOWAS & Low & 186.2 & 0.9 & 1245.9 & 5.9 \\
Mali & ECOWAS & Low & 18.9 & 0.1 & 808.5 & 3.8 \\
Nigeria & ECOWAS & Low & 3065.2 & 15.5 & 1080 & 5.1 \\
Senegal & ECOWAS & Low & 460.9 & 2.3 & 465.9 & 2.2 \\
Togo & ECOWAS & Low & 231.8 & 1.2 & 125.3 & 0.6 \\
Algeria & NA & Medium & 545.1 & 2.8 & 369.9 & 1.7 \\
Egypt & NA & Medium & 700.9 & 3.5 & 743.3 & 3.5 \\
Morocco & NA & Medium & 379.7 & 1.9 & 753.2 & 3.5 \\
Sudan & NA & Low & 52.6 & 0.3 & 220.3 & 1.0 \\
Tunisia & NA & Medium & 512.1 & 2.6 & 481.8 & 2.3 \\
Kenya & EA & Low & 924 & 4.7 & 653.6 & 3.1 \\
Uganda & EA & Low & 173.2 & 0.9 & 626.4 & 2.9 \\
Eritrea & EA & Low & - & - & - & - \\
Ethiopia & EA & Low & 88.8 & 0.4 & 138.3 & 0.7 \\
Djibouti & EA & Low & 212.3 & 1.1 & 99 & 0.5 \\
KEY & & & & & & \\
High IDI & Upper IDI & Medium IDI & LOW IDI & & & \\
6.16-8.40 & 4.09-6.04 & $2.59-4.05$ & $0.83-2.55$ & & & \\
\hline & & & & & &
\end{tabular}

Table 2 shows that in SADC, South Africa accounted for by far the largest share of exports to Africa. The two dominant exporting countries in ECOWAS were Nigeria and Cote d'Ivoire, while in East Africa exports were supplied mainly by Kenya. In North Africa region, Tunisia, Algeria and Egypt were the main exporters to Africa.

African countries sourced about $90 \%$ of their imports from outside the continent (e.g. EU and China) (IMF, 2008). Nevertheless, Table 2 shows South Africa as the dominant African importer in the SADC region, In ECOWAS, Nigeria, Ghana and Cote-d'Ivoire were the largest importers, while in East Africa it was Kenya and Uganda and in North Africa, it was Egypt and Morocco.

\section{ICT infrastructure in select African countries}

The ITU (2011) has developed a composite index to monitor and compare development of ICT across countries. The index, called as the ICT Development Index (IDI), reflects the level of ICT readiness, ICT intensity and ICT skills, respectively, in a country (ITU, 2011). Indicators of ICT readiness include fixed-telephone line penetration, mobile-cellular telephone subscriptions, international Internet 
bandwidth (bit/s) per Internet user, percentage of households with a computer and percentage of households with Internet access (ITU, 2012). ICT intensity indicators include percentage of individuals using the Internet, fixed (wired)-broadband Internet subscription rates and active mobile-broadband subscription rates (ITU, 2012). ICT skills are measured with reference to adult literacy rate, secondary gross enrollment ratio and tertiary gross enrollment ratio (ITU, 2012).

In 2011, only three African countries were ranked in the top 100, these being Mauritius (4.00), Seychelles (3.94) and South Africa (3.00) (ITU, 2011). The cost of some ICT services in South Africa (e.g. broadband Internet) is exorbitant, putting them out of reach for large sections of the population (Brown et al., 2007). This pulls its ranking down.

ITU (2011) further classifies countries as having either a high (6.16-8.40), upper (4.09-6.04), medium (2.59-4.05) or low (0.83-2.55) IDI. All African countries, including the aforementioned three fall within either the medium or low categorization. Amongst the 28 countries listed in Table 2, South Africa, Mauritius and Botswana were the SADC countries with medium IDI. In the ECOWAS region, only Cape Verde had a medium IDI, whereas in North Africa all of Algeria, Morocco and Tunisia had medium level IDI. None of the East African countries had a medium level of IDI.

The rankings highlight the relative sophistication and pervasiveness of ICTs in the North African region, and to a lesser extent in SADC, with general low levels of development in the East African and ECOWAS regions.

\section{Theoretical background}

Trade openness is essential for socio-economic development. Every nation engages in trade transactions to reap economic benefits (Chikhasu, 2007). The economic theory of trade relies on the reality that countries have different resource endowments, preferences, technologies and economic and social institutions which can be exchanged and used to facilitate growth and human development (Farole, Reis, \& Wagle, 2010). Consequently, countries formulate and pursue policies that enhance their trade competitiveness. Trade competitiveness is a county's inherent ability to compete efficiently in the global economy and to sustain improvements in their own real output and wealth (Chikhasu, 2007; UNECA, 2004). It can also be referred to as the degree of trade performance, export competitiveness and diversification (Farole et al., 2010).

In Africa, there has been a long history of discussions on trade and regional integration following the establishment of independent nations in the 1960 s (UNCTAD, 2009; UNECA, 2010). While several initiatives have been embarked on to further the process of integration, the World Trade Organization has also mandated the Organization of Economic Cooperation and Development countries to reduce agricultural subsidies, domestic support measures that are distorting global trade and marginalizing Africa in international trade (UNECA, 2004). There have been arguments that strengthening Africa's trade capability through the loosening of 
policies is not the only step that can be taken to successful integration of African countries into the global economy and development. Africa's trade capability can be improved by other factors that assist the growth of their export sector, such as ICT infrastructure, physical and human capital development and trade facilitation services (UNECA, 2004).

In response to these assertions, the New Partnership for Africa's Development and the UNECA formulated a framework for measuring trade facilitation known as the Trade Competitiveness Index (TCI) (Chikhasu, 2007; UNECA, 2004, 2006). The TCI has three dimensions, where each captures a different aspect of trade competitiveness. These dimensions are: trade enabling environment (TEE, e.g. institutional quality and macro policy), productive resources (e.g. labor force and geography) and infrastructure (e.g. transport networks, energy, telecommunications and access to information) (UNECA, 2004). These dimensions are key determinants of trade, and hence intra-African trade. For each dimension, a key indicator is selected for this study, and the influence of the indicator on intra-African trade is postulated.

\subsection{TEE (institutional quality)}

The TEE dimension mirrors the overall economic and political environment and its suitability for trade transactions. It considers the quality of national institutions such as government stability, democratic accountability, rule of law (i.e. Institutional Quality) and the overall macroeconomic policies that are relevant to trade (UNECA, 2004). Institutional Quality was selected as the key indicator of a TEE in this study, as for attaining high levels of trade and economic transactions an effective legal and economic environment is required (UNECA, 2004). This is achievable with a government that reforms the rules and regulations that govern the interaction of citizens as well as the enforcement of rights, responsibilities, wealth redistribution and control of inflation (Shiraz et al., 2009). A thriving trade-based economy require appropriate regulations of financial markets, a defensive rule of law, the protection of property rights and institutions that fight against corruption (Barro, 1997; Rodrik, 2000). Any country with unstable institutions, such as corruption in administration, and weak legal systems does not attract the required capital for production and export (Gyimah-Brempong, 2002; Gyimah-Brempong \& Camacho, 2006; Gyimah-Brempong, Padisson, \& Mituku, 2006; Gyimah-Brempong \& Racine, 2010; UNECA, 2004). Shiraz et al. (2009) furthermore showed a positive relationship between institutional quality and economic freedom, an indicator of trade. The hypothesis suggested hence is:

H1: Institutional Quality positively influences intra-African trade.

\subsection{Productive resources (educational attainment)}

Productive resources measure the elements that are direct inputs to production in a country (e.g. labor and land). This dimension is used to estimate the availability of resources in a country to produce goods and services for trade transactions (UNECA, 2004). The quality of the labor force, also known as human capital, is a key productive resource in any country. Development researchers highlight 
education attainment as fundamentally representative of a quality labor force (Cohen and Soto, 2007). In this study, educational attainment is hence used as the key indicator of the productive resources dimension of the TCI. A measure for educational attainment was developed by Orbicom (2005) and ITU for capturing the level of education of a country. Education Attainment refers to the highest level of education that an individual has acquired. It is the accumulation of human capital through formal schooling or learning which affects a nation's capability to innovate or compete with other countries (Shiraz et al., 2009). This education index has been used in several similar prior studies (e.g. Bankole, Shirazi, \& Brown, 2011; Shiraz, 2010; Shiraz et al., 2009). Research on the impact of education on economic growth shows that increased levels of education have a significant effect on economic growth rates (Cohen and Soto, 2007). Educational attainment hence has a strong bearing on trade performance. The hypothesis suggested is:

H2: Educational Attainment positively influences intra-African trade.

Education attainment has a bearing too on the quality of institutions, political and economic freedom and trade transactions of citizens in a country (Shiraz et al., 2009). A more educated workforce is more likely to pressure government to improve governance and service delivery (Eicher, García-Peñalosa, \& van Ypersele, 2009) whilst also providing for a more competent and efficient civil service. Rindermann (2008) found that education strongly impacted democracy, rule of law and political liberties. The additional hypothesis suggested is:

H3: Educational Attainment positively influences Institutional Quality.

\subsection{ICT infrastructure (telecommunications)}

The infrastructure dimension of the TCI measures the availability of indirect inputs that enable the transfer of goods and services. It is a measure of the physical investments that are essential for effective trade transactions (UNECA, 2004). The issue of the high transaction costs of goods in Africa is a main cause of comparative disadvantage in manufactured exports, which are more transaction-intensive than primary production (Chikhasu, 2007; Collier, 1997). Infrastructure increases the flow of information, opening up new opportunities and reducing irregularities and other market constraints (UNCTAD, 2009). It also facilitates the mobility of the means of production, such as labor and goods, thereby improving productivity (Eustace \& Fay, 2007). The infrastructure dimension of the TCI consists of telecommunications infrastructure, energy, transport and the level of access to information available in a country (UNECA, 2004). The focus in this study is on the impact of ICT infrastructure specifically; hence, telecommunications infrastructure and access to information are pertinent indicators. Telecommunications are measured by the number of mobile subscribers, main telephone lines and Internet usage in a country, while access to information is expressed in terms of the number of personal computers, television sets and radio sets (UNECA, 2004). Telecommunications were chosen as the key indicator of ICT infrastructure, as it has arguably the greatest bearing on intra-African trade, in comparison to the pervasiveness of personal computers, TVs and radios in a country (indicators of access to 
information). Personal computers, for example, would be most effective for trade impact if Internet-enabled (a telecommunications infrastructure indicator).

Whilst much research has been conducted showing the impact of telecommunications on economic performance (Cardona, Kretschmer, \& Strobel, 2013), few studies have investigated the impact on trade specifically. Demirkan, Goul, Kauffman, and Weber (2009) found that higher Internet usage was associated with greater bilateral trade flows between countries. Similarly, Kurihara and Fukushima (2013) found Internet prevalence to be associated with international trade in Asia. In the context of developing countries, access to the Internet was shown to improve export performance (Clarke \& Wallsten, 2006). Telecommunications creates an avenue to maintain quick and effective communication with trade partners to sustain trade competitiveness, hence supporting the hypothesis that:

H4: Telecommunications infrastructure has a positive influence on intra-African trade.

Institutional quality is a multi-faceted concept that includes aspects of the rule of law, absence of corruption, bureaucratic quality and government stability (UNECA, 2004). Telecommunications infrastructure impacts institutional quality in various ways. For example, Internet adoption has been found to have a positive impact on corruption reduction (Lio, Liu, \& Ou, 2011; Shim \& Eom, 2008). Shirazi (2008) showed that ICT infrastructure had a net positive impact on democracy and freedom of expression, which could enhance government accountability and hence institutional quality. Telecommunications infrastructure provides opportunities for ICTs to be used to improve government service delivery, administrative processes and citizen engagement through, for example, e-government (Kudo, 2008). Hence the hypothesis supported is:

H5: Telecommunications Infrastructure has a positive influence on Institutional Quality.

\subsection{Conceptual framework}

The sum total of these relationships yields the conceptual model shown in Figure 3. It is worthwhile to note that no single study in the literature has explored all the relationships in either developed or developing countries, and particularly not in Africa. Hence the study offers a unique contribution to the body of knowledge on ICT infrastructure and intra-African trade.

\section{Research methodology}

The measurement model was developed and data were gathered from secondary sources according to the model structure. The data were analyzed using a twophased approach: (a) factor analysis and (b) partial least square (PLS) regression (Chin, Marcolin, \& Newsted, 2003). The methodological process involved the following. First, in order to avoid overlaps between the theoretical constructs, exploratory factor analysis was performed for the variables (both independent and dependent). Second, a PLS-based structural equation model (SEM) was used to assess both the research models, the psychometric properties and the estimation 
of the parameters of the structural model (Srite \& Karahanna, 2006). The importance of the SEM is based on its capability to simultaneously assess the relationship between the measurement model (relationship between constructs and measures) and the path model to test the theoretical relationships (Freeze \& Raschke, 2007). Consequently, the use of the SEM-based PLS in this research permits the test of relational models. This calls for sound theoretical grounding of constructs, as elaborated in the previous section. In addition, SEM describes constructs and direction of causality of the measures to avoid inappropriate conclusions regarding relationships among constructs. On account of this, it is crucial to identify both reflective (Compeau \& Higgins, 1995; Freeze \& Raschke, 2007) and formative (Freeze \& Raschke, 2007) measures. The reflective constructs in the model are ICT (telecommunications infrastructure) and institutional quality, while the formative constructs are education (primary, secondary and tertiary) and trade (total import and export of goods).

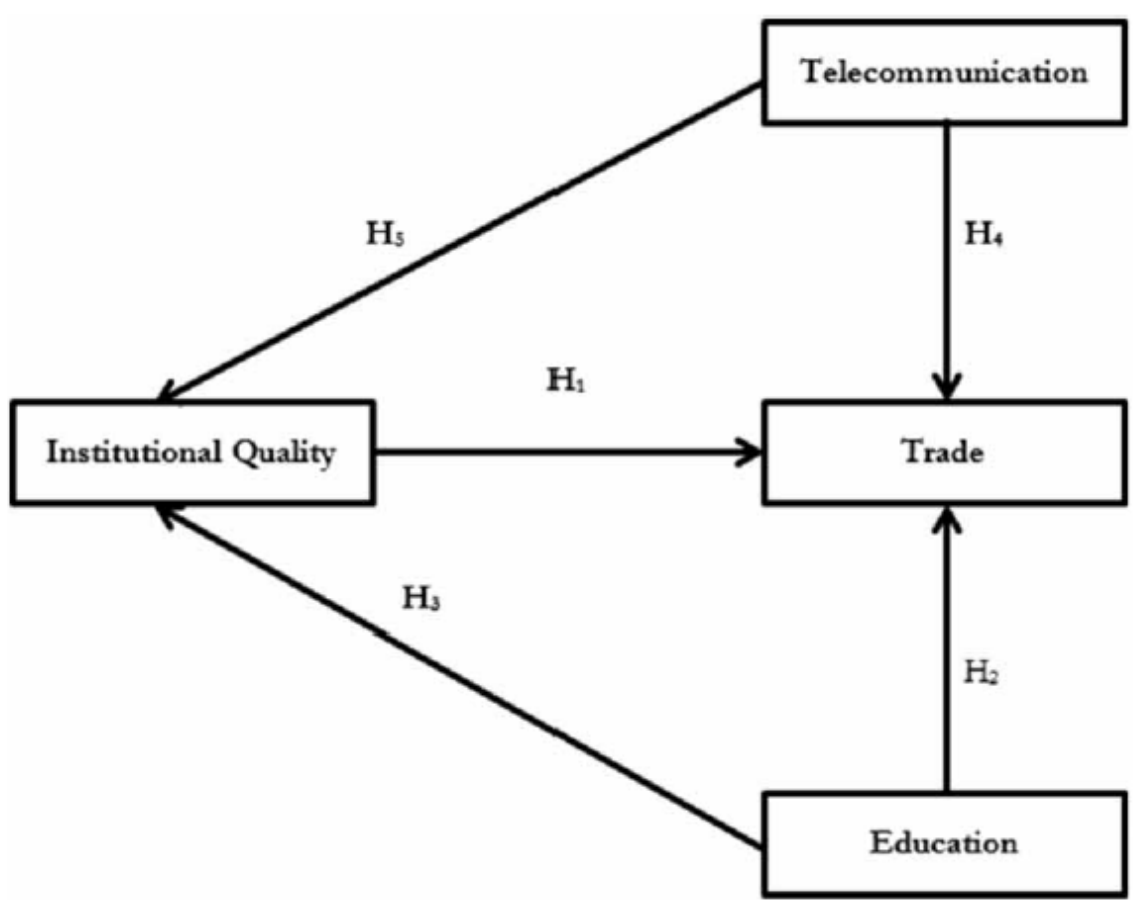

Figure 3. Impact of ICT Infrastructure and complementary factors on trade (measurement model).

\section{Description of the data}

\subsection{Data sources}

The data for this study were obtained for the period 1998-2007 from several archival sources: the ITU (for ICT infrastructure data), the World Bank (African Development Indicators and World Development Indicators) (for Institutional quality data), Orbicom (2005) for Educational Attainment data and the UNCTAD (for Trade data). The data were collected for 28 African countries which was available as at March, 2010-October, 2011.

The data-set was validated by comparing with other credible sources such as the IMF database for consistency. The data from these sources have often been used in ICT research. The ITU is one of the UN groups which has the most reliable source of data for the ICT sector. The World Bank group compiles statistical profiles for all 
countries in the world in a well-organized database. The World Bank data are presented in several dimensions such as the development indices (Human Development Index), ICT and other basic infrastructures. The UNCTAD is one of the principal organs of the UN that deals with trade, investment and other developmental issues. It was established to provide a forum for developing countries to discuss problems (formulating policies) relating to trade and economic development. The UNCTAD provides a series of data and indicators presented in multidimensional tables that illustrate new and emerging trends in the world economy covering areas such as trade, international finance, ICT, commodities and demography.

The reader will observe that the statistical data for this study were collected from different sources because they are not readily available in a single resource. Therefore, collecting and compiling the homogeneous database for this research was a challenge. The fact that ICT is a relatively new technology for most of the countries in Africa, and that there are limitations with respect to the availability of data, affected the completeness of the set of indicator variables that were used for the constructs, and in some cases the constructs were incomplete too.

\subsection{Construct measures}

Trade: Data for imports and exports were collected for all commodities (except oil, gas and minerals) for each home country and their trade partners. The exclusion of nonproductive natural resources or minerals is made in an effort to avoid distortion in the data. This is intended to avoid the bias that would give resource rich countries such as Nigeria or Botswana with very high competitive values in the data. South Africa is regarded as the home country in this study, while other African countries are trading partners. South Africa is chosen based on its high level of ICT infrastructure and trade on the continent. The 540 bilateral trade flows were collected (i.e. for each of the 27 selected countries that traded with South Africa, both import and export data were gathered for each of the 10 years from 1998 to 2007).

Telecommunications (TELECOMS): The variables that represent telecommunications are: main telephone line subscribers per 100 inhabitants $(M T L)$, Internet users per 100 inhabitants $(I U)$ and mobile cellular subscribers (MCS) per 100 inhabitants (UNECA, 2004). Other variables such as total telephone cost and price basket for Internet were not available in the data-set.

Education attainment (EDU): The educational attainment construct consists of three variables - gross primary school enrollments, secondary enrollments and tertiary enrollments, respectively. It is computed as: $\mathrm{EDU}=$ (primary $+2^{*}$ secondary $+3^{*}$ tertiary)/6 (Orbicom, 2005).

Institutional quality (IQ): For institutional quality, the following variables were applied (UNECA, 2004):

- Rule of law $(L A W)$ : This indicates the extent to which citizens or agents have confidence in and abide by the rules of society, especially the quality of contract 
enforcement, the police, the courts as well as the likelihood of crime and violence. This ranks from o to 100.

- Corruption perception (CORP): This relates to the degree of corruption as determined by expert assessment, opinion surveys, business people and country analysts. This ranges from o to 10.

- Bureaucratic quality (BQ): This is a measure of government effectiveness in terms of the quality of independence that the civil services has that protects it from political pressure, the quality of policy formulation and implementation and the credibility of the government's commitment to such policies.

- Government stability (GS): This indicates the political stability of a country. It measures the degree of absence of violence or the perceptions of the likelihood that the government will be destabilized or overthrown by unconstitutional or violent ways (domestic or terrorist).

\section{Data analysis and results}

In this research, both formative and reflective indicators were chosen. To assess the validity of formative indicators, content validity is considered to be of greatest significance (Jarvis, MacKenzie, \& Podsakoff, 2003) and reflective indicators are typically assessed using confirmatory factor analysis (CFA) (Compeau \& Higgins, 1995). Consequently, both methods were employed in assessing the model. For the reflective constructs, after performing the CFA, some of the original constructs/variables adopted in the research were eliminated from the analysis due to in appropriate loading. Following the removal of these constructs/variables, the PLS analysis was re-run and the model demonstrated a good model fit assessment as explained in the next section.

\subsection{PLSs with SEM analysis (PLS)}

After validating the constructs, the PLS-based structural equation analysis was used to assess the research model and the psychometric properties of the scales. The conditions for a model fit assessment require that the $p$-values for both average path coefficient (APC) and average $R$-squared (ARS) must be lower than 0.05, while the average variance inflation factor (AVIF) must be lower than 5 (Kock, 2010). For the psychometric properties (measurement model) assessment, the following measures were considered and presented as in Tables 3-5, respectively:

(a) Discriminant validity: For each latent variable, the square root of the average variance extracted should be higher than any of the correlations involving the latent variables (Fornell \& Larcker, 1981; Kock, 2010; Srite \& Karahanna, 2006). This applies to reflective constructs. The results given in Table 3 demonstrate that the square root of the average variance extracted (shown on the diagonal) is higher than the latent variables. The model therefore passed the test of discriminant validity.

(b) Convergent validity: The conditions are that the $p$-values associated with the loadings in factor analysis be lower than 0.05 (and that the loadings be equal to or greater than 0.5) Anderson, \& Tatham, 1987; Kock, 2010; Srite \& Karahanna, 2006). This is applicable to reflective constructs. The results given in Table 4 demonstrate that the $p$-values associated with the loadings are lower than 0.005

\section{https://repository.uwc.ac.za/}


(less than 0.001 in all cases). This shows that the model passed the measure of internal consistency (convergent validity).

(c) Reliability: Both composite reliability and the Cronbach alpha coefficients should be equal to or greater than 0.7 (Fornell \& Larcker, 1981; Kock, 2010; Nunnally, 1978; Srite \& Karahanna, 2006). This applies to reflective constructs. The values of the loadings of measures given in Table 5 show that the model passed the reliability assessment. The composite reliability coefficients and Cronbach alpha coefficients of individual loading items are greater than 0.7. This indicates that the measures and the constructs have a significant amount of variance.

\subsection{Discussion of results}

The $R^{2}$ of the PLS analysis for Intra-African Trade was 0.40. This suggests that $40 \%$ of the variance in trade flows is explained by the statistically significant independent variables in the model (i.e. Telecommunications Infrastructure and Institutional Quality). Educational Attainment was found to only have an indirect impact on intra-African Trade, through Institutional Quality. When considering the influence of Telecommunications Infrastructure on Institutional Quality, the $R^{2}$ values were 0.40 . These results are acceptable because several other possible factors (predictors) were not included in the model for the sake of parsimony. Variables such as electricity (production and consumption), transport networks (roads, rail, air and water), telephone call cost, landlocked area, actual renewable water resources and other variables would have extended the model construction. Nonetheless, the $p$-values of both APC and ARS and AVIF were acceptable (Figure 4). This shows a good model fit, thus allowing for technical discussion of the results. The model of Figure 4, in summary, provides support for four of the five hypotheses as follows:

(i) H1 SUPPORTED - Institutional Quality has a positive statistically significant influence on Intra-African Trade ( $b$ 1/4 .43, $p$ 1/4 .05). The result confirms that the existence of quality institutions (e.g. government stability, bureaucratic quality, rule of law and lack of corruption) enhance trade flows between African countries.

(ii) H2 NOT SUPPORTED - Educational Attainment was found to have a weak and non-significant relationship with Intra-African Trade (b $1 / 4$. $13, \quad p \quad 1 / 4$.24). Nevertheless, there was an indirect effect through Institutional Quality as discussed below. The results suggest that further research is needed to determine the role of Educational Attainment in improving intra-African Trade. Educational Attainment was chosen in this study to represent the quality of the labor force of a country. The results hence suggest more research on how to conceptualize the quality of the labor force in order to understand better its role in improving intra-African Trade. 
Table 3. Discriminant validity.

\begin{tabular}{lcccc}
\hline \multicolumn{1}{l}{ Correlations among latent variables } & & & \\
\hline & TELECOMS & TRADE & EDU & IQ \\
\hline TELECOMS & $\mathbf{( 0 . 8 8 2 )}$ & 0.358 & 0.321 & 0.367 \\
TRADE & 0.358 & $\mathbf{( 0 . 9 2 5 )}$ & 0.282 & 0.283 \\
EDU & 0.321 & 0.282 & $\mathbf{( 1 . 0 0 0 )}$ & 0.497 \\
IQ & 0.367 & 0.283 & 0.497 & $(\mathbf{0 . 8 8 3})$ \\
\hline
\end{tabular}

Note: Square roots of average variances extracted (AVE's) shown on diagonal.

Table 4. Convergent validity.

\begin{tabular}{lcrrrr}
\hline & TELECOM & TRADE & EDU & IQ & $p$-Value \\
\hline MCS & $(0.860)$ & 0.065 & -0.106 & -0.074 & $<.001$ \\
MTL & $(0.840)$ & 0.009 & 0.009 & 0.110 & $<.001$ \\
IU & $(0.944)$ & -0.067 & 0.008 & -0.030 & $<.001$ \\
EXP & -0.146 & $(0.925)$ & 0.088 & -0.083 & $<.001$ \\
IMP & 0.146 & $(-0.925)$ & -0.088 & 0.083 & $<.001$ \\
EDU & -0.000 & -0.000 & $(1.000)$ & 0.000 & $<.001$ \\
LAW & 0.011 & -0.220 & 0.085 & $(0.931)$ & $<.001$ \\
CORP & -0.072 & 0.173 & 0.123 & $(0.871)$ & $<.001$ \\
GS & 0.219 & -0.012 & -0.394 & $(0.825)$ & $<.001$ \\
BQ & -0.143 & 0.050 & 0.154 & $(0.900)$ & $<.001$ \\
\hline
\end{tabular}

(iii) $\mathrm{H}_{3}$ SUPPORTED - Educational Attainment has a positive statistically significant influence on $I Q$ in Africa $(b 1 / 4.55, p, .01)$. The result confirms that higher levels of Educational Attainment in a population strongly contribute to better quality institutions. Citizens and civil servants that are more educated become aware of the benefits of the rule of law, government stability and accountability and thus work for improvement in these areas.

(iv) H4 SUPPORTED - Telecommunications Infrastructure has a positive, statistically significant influence on Intra-African Trade $(b 1 / 4.30, p>.01)$. The results confirm that the expansion and use of Telecommunications Infrastructure in a country (e.g. fixed lines, mobile phones and the Internet) facilitates an increase in Trade transactions between African countries.

(v) H5 SUPPORTED - Telecommunications Infrastructure has a positive statistically significant influence on Institutional Quality $(b 1 / 4.17, p$ - .01) in Africa. The results confirm that the existence of Telecommunications Infrastructure enhances Institutional Quality by enabling access to resource/knowledge for policies and reform and by improving efficiencies, transparency and accountability in government services (e.g. e-government).

The findings highlight the centrality of telecommunications infrastructure in improving intra-African trade. Not only is there a direct impact of telecommunications on trade, but there is also an indirect relationship through institutional quality. 


\section{Summary, recommendations and conclusion}

This study responds to the call for investigations into the impact of ICT infrastructure on trade within Africa. It looks at the role of ICT infrastructure, in the context of other complementary factors that contribute to successful trade flows. These complementary factors include institutional quality and educational attainment. By employing SEM (PLS) analysis, it was found that telecommunications infrastructure (fixed line telephony, mobile telephony and Internet usage) has key implications for intra-African trade.

Table 5. Reliability.

\begin{tabular}{llllc}
\hline RELIABILITY & TELECOMS & TRADE & EDU & IQ \\
\hline Composite reliability & 0.913 & 0.923 & 1.000 & 0.934 \\
Cronbach alpha & 0.856 & 0.832 & 1.000 & 0.905 \\
$R^{2}$ & & 0.40 & & 0.40 \\
\hline
\end{tabular}

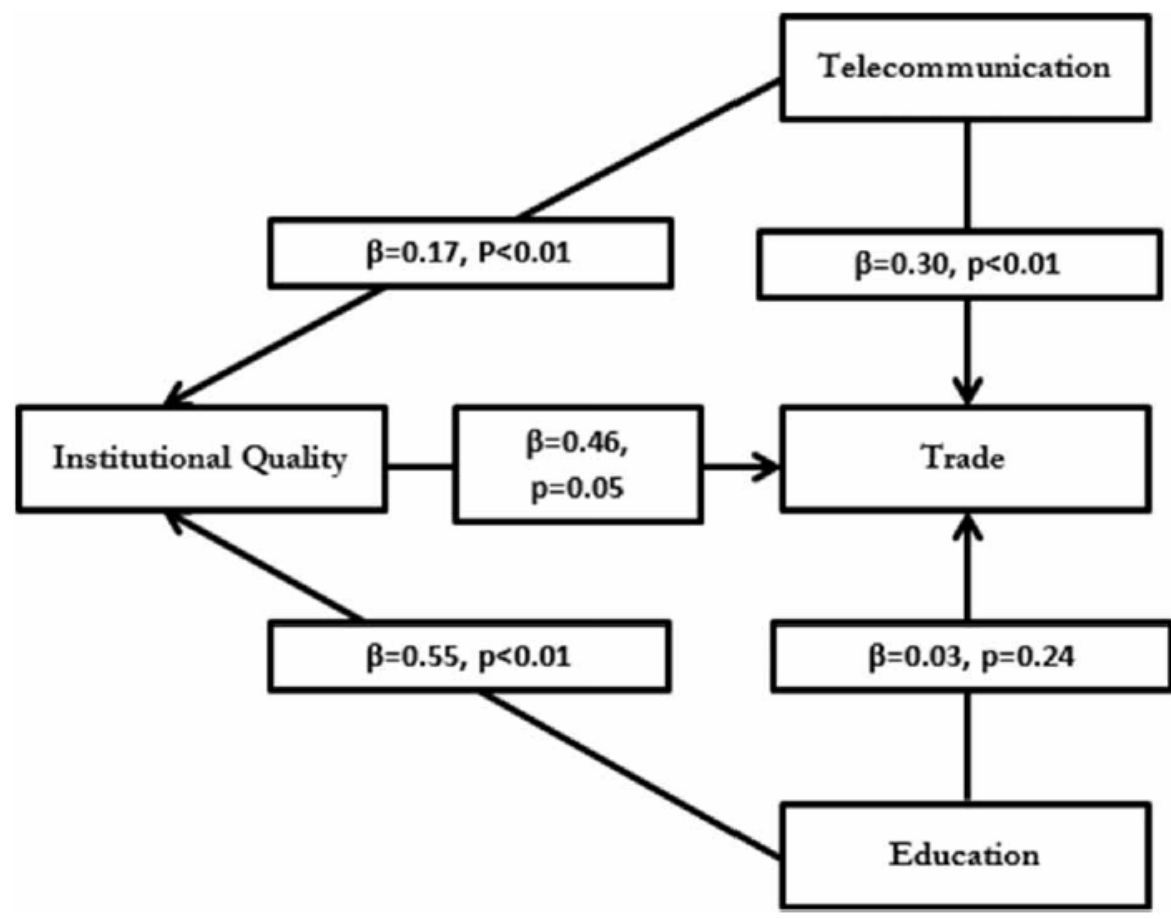

Figure 4. Structural model (PLS path analysis). Model fit: APC $=0.301, p<.001$, ARS $=0.396, p<$ $.001, \mathrm{AVIF}=1.253$, good if $<5$

Telecommunications infrastructure was found to have a direct impact on trade, as well as an indirect impact through its influence on institutional quality. Educational attainment indirectly influences intra-African trade through its impact on institutional quality. The practical implications are that government and ICT policymakers need to be cognizant of the state of telecommunications infrastructure, institutional quality and educational attainment in a nation, in order to understand their complementary impacts on trade. Methodologically by using both SEM and PLS analyses, a better and more in-depth understanding of the phenomena was achieved. 
The study has revealed many opportunities for future research. A more comprehensive model can be developed, if secondary data about variables such as electricity, transportation networks and geography can be found. Advanced techniques such as regression splines (Ko \& Osei-Bryson, 2006) can be used to explore the conditional and interacting effects on intra-African trade. One country, South Africa, was used as a point of reference, and trade between the 27 other countries in this study and South Africa was examined. Alternative points of reference such as Nigeria could be used and the findings were compared.

\section{Notes on contributors}

Felix Olu Bankole is Senior Lecturer and Coordinator of IT Infrastructure and Application Management Programme at the University of the Western Cape. He holds a PhD in Information Systems from the University of Cape Town. He is also a Research Associate at the Centre for IT and National Development in Africa (CITANDA) at the University of Cape Town. His current research interests are in the area of ICT and national development, Data Mining and Business Analytics.

Kweku-Muata Osei-Bryson is Professor of Information Systems at Virginia Commonwealth University in Richmond, VA where he also served as the Coordinator of the IS PhD program during 2001-2003. Previously he was Professor of Information Systems \& Decision Sciences at Howard University in Washington, DC. He has also worked as an Information Systems practitioner in industry and government. He holds a Ph.D. in Applied Mathematics (Management Science \& Information Systems) from the University of Maryland at College Park. His research areas include: Data Mining, Knowledge Management, IS Security, e-Commerce, IT for Development, Database Management, Decision Support Systems, IS Outsourcing, Multi-Criteria Decision Making. He has published in various leading journals including: Information Systems Journal, Knowledge Management Research \& Practice, Decision Support Systems, Information Sciences, European Journal of Information Systems, Expert Systems with Applications, Information Systems Frontiers, Information \& Management, Journal of the Association for Information Systems, Journal of Information Technology for Development, Journal of Database Management, Expert Systems with Applications, Computers \& Operations Research, Journal of the Operational Research Society, and the European Journal of Operational Research. He serves as an Associate Editor of the Journal on Computing, as a member of the Editorial Boards of the Computers \& Operations Research journal and the Journal of Information Technology for Development, and as a member of the International Advisory Board of the Journal of the Operational Research Society.

Irwin Brown is a Professor in the Department of Information Systems (IS) at the University of Cape Town. Irwin's research interests relate to issues around IS in developing countries contexts. He has published in outlets such as the European Journal of Information Systems, Communications of the AIS, Journal of Global Information Technology Management, Journal of Global Information Management, the International Journal of Information Management and Electronic Journal of IS Evaluation. 


\section{References}

Bankole, F. O., Shirazi, F., \& Brown, I. (2011). Investigating the impact of ICT investments on human development. Electronic Journal of Information Systems in Developing Countries, 48(8), 1-19.

Barro, R. J. (1997). Determinants of economic growth: A cross-country empirical study. Cambridge, MA: MIT Press.

Bollou, F. (2010). Interrogating the impact of ICT infrastructure expansion in francophone West Africa 1993 - 2005. A critical theory study using Archival data and non parametric research methods (Doctoral Thesis). University of Cape Town.

Brown, I., Collins, T., Maleka, B., Morrison, D., Muganda, N., \& Speight, H. (2007). Global diffusion of the internet X: Internet diffusion and its determinants in South Africa: The first decade of democracy (1994-2004) and beyond. Communications of the Association Information Systems, 19, 142-182.

Cardona, M., Kretschmer, T., \& Strobel, T. (2013). ICT and productivity: Conclusions from the empirical literature. Information Economics and Policy, 25(3), 109-125.

Chikhasu, D. (2007). An analysis of Malawi's trade competitiveness. Government of Malawi ministry of industry, trade and private sector development integrated framework. Policy Analysis Working Paper Series Malawi (4), 1-33.

Chin, W. W., Marcolin, B. L., \& Newsted, P. R. (2003). A partial least squares latent variable modeling approach for measuring interaction effects: Results from a Monte Carlo simulation study and an electronic-mail emotion/adoption study. Information Systems Research, 14(2), 189-218.

Christodoulopoulou, C., Garofalakis, J., \& Koskeris, A. (2006). Horizontal ICT interregional collaboration activities in the region of Western Greece. Impact on Regional Development. Regional Studies Association International Conference-Shaping EU Regional Policy: Economic Social and Political Pressures, 8-9 June 2006, Leuven, Belgium.

Clarke, G. R., \& Wallsten, S. J. (2006). Has the internet increased trade? Developed and developing country evidence. Economic Inquiry, 44(3), 465-484.

Cohen, D., \& Soto, M. (2007). Growth and human capital: Good data, good results. Journal of Economic Growth, 12(1), 51-76.

Collier, P. (1997). Policy commitment arrangements for Africa: Implications for aid, trade and investment flow. AERC Workshop on Africa and WTO, November, 1997.

Compeau, D. R., \& Higgins, C. A. (1995). Computer self-efficacy: Development of a measure and initial test. MIS Quarterly, 19(2), 189-211.

Demirkan, H., Goul, M., Kauffman, R. J., \& Weber, D. M. (2009). Does distance matter? The influence of ICT on Bilateral trade flows. Proceedings of the Second Annual SIG GlobDev Workshop, Phoenix, USA, December 14, p. 1 (Vol. 19).

Eicher, T., García-Penalosa, C., \& van Ypersele, T. (2009). Education, corruption, and the distribution of income. Journal of Economic Growth, 14(3), 205-231.

Eustace, A., \& Fay, M. (2007). Current debates on infrastructure policy. World Bank Policy Research Working Paper 4410.

Farole, T., Reis, J. G., \& Wagle, S. (2010). Analyzing trade competitiveness: A diagnostics approach. The World Bank Policy Research Working Paper 5329. 
Fornell, C., \& Larcker, D. F. (1981). Evaluating structural equation models with unobservable variables and measurement error. Journal of Marketing Research, 18(1), 39-50.

Freeze, R., \& Raschke, R. L. (2007). An assessment of formative and reflective constructs in IS research. Proceedings of European Conference on Information Systems, Paper 171. Retrieved January 12, 2012, from http://aisel.aisnet.org/ecis2007/171

Gyimah-Brempong, K. (2002). Corruption, economic growth, and income inequality in Africa. Economics of Governance, 3(2002), 183-209.

Gyimah-Brempong, K., \& Camacho, S.M. de (2006). Corruption, growth, and income distribution: Are there regional differences? Economics of Governance, $7(3), 245-269$.

Gyimah-Brempong, K., Paddison, O., \& Mitiku, W. (2006). Higher education and economic growth in Africa. Journal of Development Studies, 42(3), 509-529.

Gyimah-Brempong, K., \& Racine, J. S. (2010). Aid and investment in LDCs: A robust approach. The Journal of International Trade \& Economic Development, 19(2), 319-349.

Hair, J. F., Anderson, R. E., \& Tatham, R. L. (1987). Multivariate data analysis. New York, NY: Macmillan. International Monetary Fund. (2008). Can Africa make trade an engine for growth. Retrieved June 15, 2013, from http://www.imf.org/external/pubs/ft/survey/so/2008/boko31108a.htm

International Telecommunication Union. (2009). World information society reports. Retrieved October 15, 2011, from www.itu.int/ITU-D/ict/publications/

International Telecommunication Union. (2011). Measuring the information society 2011. Retrieved March 15, 2012, from http://www.itu.int/net/pressoffice/backgrounders/general/pdf/5.pdf

International Telecommunication Union. (2012). Measuring the information society 2012. Retrieved June 16, 2013, http://www.itu.int/en/ITUD/Statistics/Documents/publications/mis2012/MIS2012_without_ Annex_4.pdf

International Telecommunication Union. (2013). ICT facts and figures 2013. Retrieved June 15, 2013, from http://www.itu.int/en/ITUD/Statistics/Pages/stat/default.aspx

Jarvis, C. B., MacKenzie, S. B., \& Podsakoff, P. M. (2003). A critical review of construct indicators and measurement model misspecification in marketing and consumer research. Journal of Consumer Research, 30(20), 199-218.

Ko, M., \& Osei-Bryson, K-M (2006). Analyzing the impact of information technology investments using regression and data mining techniques. Journal of Enterprise Information Management,19(4),403-417.

Kock, N. (2010). Warp PLS 1.o User Manual. Laredo, TX: ScriptWarp Systems.

Kudo, H. (2008). Does e-government guarantee accountability in the public sector? Experiences in Italy and Japan. Public Administration Quarterly, 32(1), 93-120.

Kurihara, Y., \& Fukushima, A. (2013). Impact of the prevailing internet on international trade in Asia. Journal of Sustainable Development Studies, 3(1), 113. 
Lio, M. C., Liu, M. C., \& Ou, Y. P. (2011). Can the internet reduce corruption? A crosscountry study based on dynamic panel data models. Government Information Quarterly, 28(1), 47-53.

Nunnally, J. C. (1978). Psychometric theory. New York, NY: McGraw Hill.

Orbicom (2005). From the digital divide to digital opportunities: Measuring infostates for development. Montreal: Claude-Yves Charron.

Rindermann, H. (2008). Relevance of education and intelligence for the political development of nations: Democracy, rule of law and political liberty. Intelligence, 36(4), 306-322.

Rodrik, D. (2000). Institutions for high quality growth: What they are and how to acquire them. NBER Working Paper NO W7540.

Shim, D. C., \& Eom, T. H. (2008). E-Government and anti-Corruption: Empirical analysis of international data. International Journal of Public Administration, $31(3), 298-316$.

Shirazi, F. (2008). The contribution of ICT to freedom and democracy: An empirical analysis of archival data on the middle east. The Electronic Journal of Information Systems in Developing Countries, 35(6), 1-24.

Shirazi, F. (2010). The impact of ICT expansion on promoting democracy and economic freedom in the middle east (1995-2005) (Doctoral thesis). University of Cape Town, South Africa.

Shirazi, F., Gholami, R., \& Higon, D. A. (2009). The impact of information and communication technology (ICT), education and regulation on economic freedom in Islamic middle eastern countries. Information and Management, 46(9), 426-433.

Srite, M., \& Karahanna, E. (2006). The role of espoused national cultural values in technology acceptance. MIS Quarterly, 30(3), 679-704.

United Nations Conference on Trade and Development. (2008). Economic development in Africa: Export performance following trade liberalization: Some patterns and policy perspectives. Retrieved January 17, 2011, from www.prlog.org/un-economic-development-in africa-repo

United Nations Conference on Trade and Development. (2009). Economic development in Africa: Strengthening regional economic integration for Africa's development. Geneva, 2009. Retrieved January 17, 2011, from http://unctad.org/en/Docs/aldcafrica2009_en.pdf

United Nations Economic Commission for Africa. (2004). Unlocking Africa's trade potential. Economic report on Africa. Retrieved January 14, 2011, from www.uneca.org

United Nations Economic Commission for Africa. (2006). Capital flows and development financing in Africa. Retrieved January 17, 2011, from www.uneca.org

United Nations Economic Commission for Africa. (2010). Assessing regional integration in Africa IV: Enhancing intra-African trade. Addis Ababa, Ethiopia. Retrieved November 20, 2012, from www.uneca.org

United Nations Economic Commission for Africa. (2012). Assessing regional integration in Africa $V$ : Towards an African continental free trade area. Addis Ababa, Ethiopia. Retrieved June 16, 2013, from www.uneca.org 
World Bank. (2011). Africa's ICT infrastructure: Building on the mobile revolution. Retrieved December 15 , 2011, from siteresources.worldbank.org/.../AfricasICTInfrastructure_Building.PDF.

World Trade Organization. (2001). Pacifi Island forum: Ministerial Conference, Fourth Session, Doha. Retrieved June 16, 2013, from http://www.wtocenter.org.tw/SmartKMS/do/www/readDoc?document_id=7895 World Trade Organization. (2003). World trade report 2003 - Trade and development. Retrieved June 16, 2013, from www.wto.org

World Trade Organization. (2008). World trade report 2008 - Trade in a globalizing world. Retrieved June 16, 2013, from www.wto.org 